\title{
Peranan Kearifan Lokal Dalam Pembentukan Karakter Peserta Didik
}

\author{
Arni Naiyya Balaya, ${ }^{, *}$, Ashif Az Zafi,2 \\ ${ }^{\mathrm{a}, \mathrm{b}}$ IAIN Kudus \\ 1'arninafiyya01@gmail.com; ${ }^{2}$ ashifazzafi@iainkudus.ac.id \\ *korespondensi penulis
}

Naskah diterima: 12 Maret 2020, direvisi: 20 Maret 2020, disetujui: 24 Maret 2020

\begin{abstract}
Abstrak
Penelitian ini dilakukan karena bertujuan untuk menambah pengetahuan tentang bagaimana peranan kearifan lokal dalam pembentukan karakter peserta didik. Penelitian yang dilaksanakan oleh penulis menggunakan metode atau rancangan penelitian literatur yaitu penelitian yang bersumber pada data sumber kepustakaan. Penelitian ini dilaksanakan dengan mengandalkan sumber-sumber kepustakaan. Teknik pengumpulan data berupa data sekunder atau bukti yang diambil melalui literatur ataupun berdasarkan pustaka acuan yang ada. Hasil dari penelitian yang telah dilakukan adalah peranan kearifan lokal cukup besar sebagai pembentukan karakter peserta didik, karena karakter anak terbentuk berdasarkan kebiasaan-kebiasaan yang sering mereka lakukan, selain dari orang tua faktor lingkungan dan budaya juga berpengaruh di dalamnya.
\end{abstract}

Kata-kata kunci: Kearifan lokal, karakter

\section{Abstract}

This research was conducted because iams to increase knowledge abaout how the role pf local widom in shaping the character of students. Research ccarried out by the author uses the method or design of literary research that is research sourced from library sources. This research was conducted by relying on library sources. Data collection techniques in the form of secondary data or evidence taken though literature or based on existing reference libraries. The result of the researchthat has been done is the role of local wisdom is quite large as the character formation of students, because the character of children is formed based on habits that they often do, apart from parents environmental and culture factors influence it.

Keywords: Local wisdom, Character 


\section{Pendahuluan}

Karakter merupakan persoalan yang tidak ada habisnya untuk dibicarakan, khususnya pada negara kita Indonesia. Saat ini semakin banyak para pejabat yang tertangkap karena kasus korupsi, tidak hanya itu yang lebih mengkhawatirkan lagi ialah saat ini mulai marak kasus pembunuhan yang tersangkanya adalah anak dibawah umur dan banyak lagi kasus kekerasan yang terjadi oleh anak. Hal tersebut menjadi tanda ada sesuatu yang berubah pada diri manusianya. Ada suatu permasalahan yaitu menurunnya kualitas karakter yang tertancap dalam pribadi manusia. Apa yang terjadi saat ini menunjukkan masih banyaknya perilaku amoral pada anak. Timbulnya perilaku amoral pada anak merupakan bukti lunturnya nilai karakter pada anak. Padahal karakter itu merupakan aspek yang sangat penting dari sebuah bangsa. Bangsa yang baik ialah bangsa yang mendahulukan nilai karakter di dalamnya.

Karakter yang merupakan idiologi bangsa bisa terbentuk dari adanya keberagaman kearifan lokal, hal tersebut telah teruji mampu menciptakan bangsa ini menjadi bangsa yang bermartabat dan disegani oleh bangsa lain.Pengenalan nilai-nilai kearifan lokal kepada peserta didik merupakan hal yang penting. Karena nilai-nilai kearifan lokal merupakan salah satu bagian dari wujud kekayaan budaya bangsa. Dengan nilai kearifan lokal yang tertanam pada diri peserta didik bisa menjadikan benteng dari pengaruh budaya luar yang sangat menyimpang dari budaya kita. Apalagi usia peserta didik merupakan usia yang rentan terpengaruh oleh zaman.

Permasalahannya saat ini nilai-nilai kearifan lokal saat mulai terabaikan semenjak berkembangnya teknologi dan informasi. Semua itu bisa terlihat dari tidak terserapnya dan mewujudnya dalam perilaku sehari-hari. Kebudayaan-kebudayan lokal mulai tergerus oleh tatanan gaya hidup yang mengandung unsur kapitalistik-pragmatis. Hal ini ditandai dengan munculnya berbagai macam penyimpangan sosial. Seperti munculnya pergaulan bebas, persaingan yang berujung pertikaian, penyalahgunaan narkoba, pembunuhan, penipuan. Semua itu merupakan sebagian kecil dari contoh tatanan gaya hidup masa kini. Kerusakan alam yang disebabkan oleh manusia juga merupakan bukti dari nilai kearifan lokal yang diabaikan (Sularso, 2016)

Faktor yang menyebabkan permasalahan tersebut adalah karena kurangnya kepekaan setiap warga dalam menindak lanjuti perkembangan zaman khususnya dalam hal berkembangnya teknologi dan informasi yang sangat cepat saat ini. Semakin banyaknya tindak kriminal yang dilakukan oleh anak-anak remaja merupakan sebab dari kurangnya perhatian keluarga maupun lingkungan sekitarnya dan orang yang lebih dewasa diatas nya untuk selalu mengawasi tindak lakunya dalam perkembangan zaman atau teknologi ini. Bahkan seharusnya kewajiban mereka untuk memberikan contoh yang baik untuk peserta didik itu tidak dilaksanakan dengan baik. banyak anak yang melakukan penyimpangan karena dia meniru dari orang yang lebih dewasa atau bahkan memang penyimpangan merupakan hal sudah lumrah dikalangan masyarakat disekitarnya.

Upaya yang bisa kita lakukan untuk menyelesaikan hal tersebut salah satunya dengan cara mengembalikan nilai-nilai yang hampir terkikis oleh zaman kepada nilai budaya sekitar yang sebelumnya sudah ada pada tiap-tiap daerah. Melalui teknik pendidikan yang cenderung menekankan tentang pendidikan berbasis kearifan lokal bisa dijadikan sebagai salah satu solusi karena, salah satu faktor yang membentuk baik buruknya karakter peserta didik adalah faktor kebudayaan di lingkungan sekitar. Di dalam potensi kearifan lokal terdapat makna yang 
komprehensif karena potensi tersebut di dapat berdasarkan dari hasil pengalaman. Bahkan orang yang masih menanamkan nilai kearifan lokal pada dirinya ia lebih konsisten dalam menjaga lingkungan sekitar. Maka dari itu pembelajaran yang lebih menekankan kepada potensi kearifan lokal bisa digunakan sebagai upaya penyusunan karakter peserta didik.

Kearifan lokal tidak terlepas dari budaya dan budaya merupakan salah satu faktor yang membuat peserta didik tumbuh dan perkembang, melalui budaya lingkungan setempat lalu berkembang pada budaya yang bersifat universal yang selama ini dianut oleh manusia dan juga budaya nasional yang merupakan lingkungan yang lebih luas. Jika peserta didik sudah mulai asing terhadap budaya disekitarnya sendiri kemungkinan besar dia juga tidak akan mengenal budaya bangsanya. Melalui kondisi seperti itu peserta didik sangat mudah terpengaruh oleh budayabudaya luar terlebih mereka akan condong menganut budaya asing tanpa adanya peninjauan. Terjadinya kecondongan tersebut disebabkan mereka tidak memegang erat nilai dan norma budaya nasional yang ada padahal nilai dan norma tersebut dapat digunakan sebagai dasar dalam mempertimbangkan budaya luar yang masuk.

Terdapat juga penelitian yang membahas tentang integrasi nilai-nilai kebijakan budaya lokal dalam pembentukan karakter siswa. Penelitian yang dilakukan Sulasmono (2017) disimpulkan bahwa nilainilai budaya lokal bermanfaat untuk digunakan sebagai standar karakter di sekolah menengah pertama dan lebih banyak penelitian yang berfokus pada pengaruh faktor efektivitas nilai-nilai enkulturasi kearifan budaya.

Penelitian yang membahas tentang kearifan lokal sebagai bahan pembelajaran pendidikan karakter nilai-nilai pupuh Sunda. Penelitian ini dilakukan oleh Damayanti (2018) hasil yang didapat dalam penelitian tersebut adalah nilai gotong royong dalam pupuh asmarandana, sinom, balakbak, ladrang, pucung, lambang dan lain sebagainya. Inti dari penelitian tersebut adalah bahwa bahasa sunda pupuh memiliki banyak nilai pendidikan karakter yang relevan untuk diajarkan dan digunakan sebagai bahan belajar di sekolah.

Penelitian yang dilakukan oleh Nursyifa (2018) keberadaan Perkampungan Budaya Betawi Setu Babakan dapat menjadi wadah untuk mengenalkan nilai-nilai kearifan local kepada siswa, dengan demikian siswa dapat menerapkan budaya local dalam kehidupan sehari-hari sehingga tidak mudah terjerumus kedalam arus budaya luar yang negatif.

Penelitian yang dilakukan Mustika (2018) Penelitian yang dilakukan tentang pendidikan karakter berbasis kebijakan lokal dalam mengajar untuk mencapai integrasi nasional bangsa. Hasil dari penelitian ini ialah pendidikan karakter harus disinergikan dengan kearifan lokal masyarakat pada tiap-tiap daerah. Karena, tiap-tiap daerah pasti memiliki nilai-nilai budaya sendiri yang bisa untuk dijadikan pedoman menuju sikap. Pendidikan karakter yang disinergikan dengan kearifan lokal bertujuan mencapai visi integrasi dan keharmonisan sosial suatu bangsa.

Maksud dari penelitian ini yaitu untuk menambah pengetahuan tentang peranan kearifan lokal dalam pembentukan karakter peserta didik. Pemilihan penelitian ini berdasarkan dari studi literatur yang peneliti analisis. Kearifan lokal memiliki peranan yang cukup besar dalam proses terbentuknya karakter peserta didik.

\section{Metode}

Penelitian ini menggunakan metode atau rancangan penelitian literatur yaitu penelitian yang bersumber pada data sumber kepustakaan. Penelitian ini dilaksanakan dengan mengandalkan sumber-sumber kepustakaan. Teknik pengumpulan data berupa data sekunder atau bukti yang bersumber dari 
literatur maupun berdasarkan pustaka acuan yang ada.

\section{Hasil dan Pembahasan}

\section{Kearifan Lokal}

Secara harfiah kearifan lokal berusul dari dua kata yaitu kearifan (wisdom) dan lokal (local). Sedangkan secara istilah kearifan lokal dapat dipahami sebagai pemikiran tentang kegiatan domestik yang mengandung sifat kebijaksanaan, dipenuhi dengan kearifan, mengandung nilai elok yang sudah mengakar dan seluruh masyarakat sudah mengikutinya. Terbentuknya kearifan lokal digunakan sebagai hal yang diunggulkan oleh suatu budaya yang dimiliki oleh masyarakat domestik maupun keadaan geografis secara luas (Husain, 2016). Kearifan lokal merupakan bentuk budaya yang sudah ada pada masa nenek moyang dahulu dan harus terus dilestarikan suntuk dijadikan pedoman hidup. Meskipun nilai yang tertanam bersifat lokal tetapi nilai tersebut sudah dianggap sangat universal .

Definisi lain dari kearifan lokal yaitu suatu bentuk subtansi budaya domestik yang di dalamnya terkandung pandangan hidup dan kebijakan hidup. Kearifan lokal bukan sebatas berlaku secara lokal sebagian budaya, etnik atau sebagian suku saja tetapi, juga mencakup seluruh budaya atau etnik sehingga dapat terbentuklah potensi budaya yang mengandung sifat nasional.

Kesimpulan yang dapat ditarik dari pemaparan diatas yakni bahwa kearifan lokal adalah bentuk kearifan daerah setempat yang mengandung suatu ide pikiran dan pengetahuan domistik yang mengandung sifat penuh kearifan, bijaksana, mengandung nilai baik, berbudi luhur dan dijadikan pedoman serta dilakukan oleh masyarakat sekitar. Terdapat beberapa konsep yang termaktub dari definisi kearifan lokal, yaitu:

a. Kearifan lokal merupakan suatu pengetahuan yang kemudian diendapkan menjadi panduan seseorang dalam bertingkah laku

b. Kearifan lokal menggambarkan suatu hal yang tidak bisa dipisahkan dengan lingkungan pemiliknya

c. Kearifan lokal berguna sebagai benteng dari iklim global yang yang sedang mewabah dalam kehidupan.

d. Kearifan lokal merupakan produk buatan manusia yang digunakan dalam mempertahankan hidup

Menurut Prof. Nyoman (dalam Chairiyah, 2013) dalam masyarakat kearifan lokal berbentuk berupa nilai, norma, etika, kepercayaan, adat-istiadat, dan peraturanperaturan tertentu. Oleh karena itu, karena memiliki bentuk yang beragam dan hidup di dalam beraneka macam budaya masyarakat maka fungsinya menjadi beragam pula. Lingkup tentang kearifan lokal dapat dibagi menjadi delapan, yaitu:

a. Mengembangkan norma-norma lokal dalam wujud kewajiban dan pantangan

b. Ritual dan kebiasaan yang dilakukan masyarakat yang mengandung suatu makna yang tersirat di dalamnya

c. Lagu-lagu rakyat, mitos, legenda, dan dongeng rakyat yang menyimpan amanat tertentu yang mana hal tersebut hanya dikenali oleh masyarakat sekitar

d. Pengetahuan tentang informasi data yang terkumpul pada sesepuh atau pemangku adat atau pemimpin keagamaan

e. Masyarakat meyakini tentang kebenaran yang terkandung dalam kitab-kitab suci

f. Cara berkomunikasi domistik sebagai wujud pemenuhan dalam kehidupan sehari-hari

g. Alat-alat dan bahan yang dipergunakan sebagai bagian dari pemenuhan keperluan hidup

h. Dalam pemenuhan kehidupan seharihari masyarakat mengandalkan keadaan situasi sumber daya alam atau 


lingkungan yang dapat diambil
manfaatnya.

\section{Karakter}

\section{a. Pengertian Karakter}

Penafsiran Kamus Besar Bahasa Indonesia (2011) tentang karakter yakni semacam sifat-sifat kerohanian yang berupa akhlak atau budi pekerti yang dijadikan pembeda antara seseorang satu dengan orang lainnya( KBBI: 204). Sedangkan arti karakter secara bahasa merupakan kata serapan dari bahasa Inggris yakni charakter. Karakter merupakan suatu jenis kata sifat sebagai bentuk gambaran ciri khas atau typical khusus dari suatu hal, yang merujuk pada perilaku negatif maupun perilaku postif yang dimiliki seseorang dan itu merupakan sebagai ciri khas pembeda antara orang satu dan orang lainnya (Dharma. K, 2011).

Menurut Muslich (2011) karakter merupakan nilai-nilai unggah-ungguh yang dimiliki oleh setiap individu yang hubangannya berkaitan dengan Tuhan Yang Maha Esa, antar setiap individu, lingkungan, individu itu sendiri maupun kebangsaan yang semua hal tersebut diwujudkan melalui perasaan, fikiran, perkataan sikap dan segala perbuatan yang berlandaskan pada normanorma agama, budaya, hukum, unggahungguh, dan adat istiadat. Sedangkan Samani (2011) mengungkapkan pendapatnya yaitu karakter dapat diartikan sebagai wujud potensi dasar yang menciptakan kepribadian seseorang, yang terwujud berdasarkan hereditas maupun dampak dari lingkungan sekitar, yang dapat membedakanya dengan individu lainnya, sehingga terwujud melalui perilaku dan sikap pada kehidupannya seharihari. Wibowo (2012) juga menyampaikan pendapat yang senada mengenai karakter, menurutnya karakter merupakan suatu teknik berpikir dan kepribadian seseorang yang merupakan suatu keistimewaan setiap individu dalam menjalankan hidup dan bekerja sama, baik dalam lingkup keluarga maupun masyarakat bahkan bangsa dan negara sekalipun.

Karakter merupakan sebuah tanda khusus yang terdapat dalam setiap individu. Tanda khusus tersebut bersifat asli dan sudah tertanam dalam pribadi setiap perorangan, dan merupakan suatu alat yang bisa menjadi dorongan seseorang dalam memilih tindakan, bersikap, berkomunikasi, dan menanggapi persoalaan (Jamal. M, 2011). Sedangkan menurut Maksudin (2013) maksud dari karakter yakni ciri khusus yang dimiliki oleh masing-masing individu tentang jati dirinya (berasal dari qolbu) yang merupakan saripati dari kualitas jiwa/ mental, cara dalam berperilaku (sikap dan kegiatan jasmani), dan cara berfikir seseorang dalam hidupnya yang termasuk dalam hal bekerjasama dengan keluarga, masyarakat dan lain sebagainya.

Menurut pemaparan para ahli diatas dapat ditarik kesimpulan bahwa karakter adalah sesuatu yang terdapat pada setiap individu untuk dijadikan sebagai ciri khusus kepribadian seseorang dan diguanakan sebagai pembeda atara orang satu dan orang lainnya. Kegunaan ciri khas tersebut sebagai alat untuk bekerjasama dan hidup dalam lingkungan keluarga maupun masyarakat.

\section{b. Komponen-komponen karakter yang baik}

Karakter yang baik (componens of good charachter) mengandung tiga komponen, yang mana hal tersebut dipaparkan oleh Lickona dan diterjemahkan oleh Wamaungo (2012) sebagaimana berikut:

1) Pengetahuan moral

Pengetahuan moral adalah suatu hal yang paling urgen untuk diterapkan. Sebagai tujuan pendidikan karakter yang diingankan terdapat enam aspek yang menonjol.

a) Pemahaman moral

b) Wawasan tentang nilai moral

c) Penyikapan sudut pandang

d) Gagasan moral 
e) Penentuan dalam menentukan keputusan

f) Wawasan yang dimiliki oleh setiap individu

\section{2) Perasaan moral}

Sifat emosional merupakan suatu hal yang berperan penting. Sebatas mengetahui hal yang benar tidak bisa dijadikan jaminan individu tersebut selalu berbuat baik. Manusia menjadi berkarakter jika ia mampu menerapkan enam aspek emosi, yakni:
a) Hati nurani
b) Martabat
c) Belas kasih
d) Menyukai hal baik
e) Mengendalikan diri
f) Memiliki sifat rendah hati

\section{3) Tindakan moral}

Tindakan moral merupakan pengaruh dari adanya pemahaman moral dan perasaan moral. Dalam hal ini terdiri dari tiga aspek, yakni:
a) Kemampuan
b) Harapan
c) Kepiawaian

Jadi, setiap individu yang mempunyai kepribadian yang baik ialah jika mereka mengetahui pengetahuan moral, perasaan moral, dan tindakan moral yang bisa saling bekerjasama secara berkesinambungan. Dalam hal ini pendidikan karakter dituntut mampu membuat peserta didik mempunyai perilaku yang baik agar bisa menjadi suatu rutinitas yang sudah diterapkan dalam kehidupan kesehariannya.

\section{c. Nilai-nilai karakter yang harus ditanamkan}

Nilai-nilai karakter dan budaya bangsa berasal dari teori-teori pendidikan, nilai-nilai sosial budaya, pedoman religi, psikologi pendidikan serta suatu pengalaman yang paling baik dan praktek nyata yang diterapkan pada kehidupan sehari-hari (Zubaedi, 2011). Menurut Wibowo (2012) Kemendiknas memaparkan delapan belas nilai dalam pendidikan budaya dan karakter bangsa, yakni:

1) Relegius

Sikap patuh dalam menjalankan ajaran agama

2) Jujur

Perilaku yang berupaya supaya dirinya pantas untuk diberi amanat

3) Toleransi

Sikap tenggang rasa terhadap adanya perbedaan

4) Disiplin

Merupakan suatu perilaku yang menunjukkan sikap tertib

5) Kerja keras

Sikap yang menunjukkan keulet atau kesungguh-sungguhan

6) Kreatif

Berpikir dan melakukan hal-hal yang bisa menghasilkan suatu karya

7) Mandiri

Perilaku yang tidak mengandalkan belas kasih orang lain

8) Demokratis

Menganggap sama semua hak dan kewajiban yang dimiliki oleh dirinya maupun orang lain.

9) Rasa ingin tahu

Suatu perilaku yang menununjukkan rasa penasarannya.

10) Semangat berkebangsaan

Mengutamakan kepentingan bangsa

11) Cinta tanah air

Wujud sikap yang menggambarkan kesetian dan perhatian terhadap bangsanya

12) Menghargai prestasi

Perilaku menghargai kesuksesan orang lain

13) Bersahabat dan komunikatif

Tingkah laku yang menunjukkan pribadi yang supel atau mudah bergaul

14) Cinta damai

Sikap yang menimbulkan kenyamanan pada orang lain 
15) Gemar membaca

Hobi membaca

16) Peduli lingkungan

Sikap selalu melindungi lingkungannya dan mencegahnya dari kerusakan

17) Peduli sosial

Sikap rasa kemanusian terhadap orang lain

18) Tanggung jawab

Perilaku selalu melaksaknakan tugas dengan baik.

Peranan kearifan lokal cukup besar sebagai pembentukan karakter anak, karena karakter anak terbentuk berdasarkan kebiasaan-kebiasaan yang sering mereka lakukan, selain dari orang tua faktor lingkungan juga berpengaruh di dalamnya.

Jika dilihat dari penelitian terdahulu yang sudah dijabarkan oleh penulis dalam pendahuluan semua penelitian tersebut dapat disimpulkan hasilnya bahwa peranan kearifan lokal dalam pembentukan karakter peserta didik itu cukup berpengaruh. Jadi, dengan kembali kepada potensi-potensi kearifan lokal peserta didik bisa mempunyai kepribadian yang baik, yang sesuai dengan norma-norma yang berlaku.

\section{Kesimpulan}

Kearifan lokal adalah bentuk kearifan daerah setempat yang mengandung gide pemikiran dan pengetahuan domestik yang memiliki sifat penuh kearifan, bijaksana, mempunyai nilai baik, berbudi luhur dan dijadikan pedoman serta dilakukan oleh masyarakat sekitar. Konsep dalam kearifan lokal adalah: (a) Kearifan lokal merupakan suatu pengetahuan yang kemudian diendapkan menjadi panduan seseorang dalam bertingkah laku, (b) Kearifan lokal menggambarkan suatu hal yang tidak bisa dilepaskan dari lingkungan pemiliknya , (c) Kearifan lokal berguna sebagai benteng dari iklim global yang yang sedang mewabah dalam kehidupan, (d) Kearifan lokal merupakan produk buatan manusia yang digunakan dalam mempertahankan hidup.

Sementara karakter yakni suatu hal yang dimiliki oleh masing-masing individu yang bisa dijadikan sebagai ciri khas kepribadian seseorang dan diguanakan sebagai pembeda atara orang satu dan orang lainnya. Kegunaan ciri khas tersebut sebagai alat untuk bekerjasama dan hidup dalam lingkungan keluarga maupun masyarakat. Peranan kearifan lokal dalam pembentukan karakter peserta didik cukup penting, karena pembentukan karakter itu sesuai dengan kebiasaan yang dilakukan. dan dengan menerapkan nilai kearifan lokal akanmembentuk karakter yang baik.

\section{Referensi}

Chairiyah. (2013). "Implemetasi Pendidikan Karakter Melalui Nilai-nilai Kearifan Lokal di Sd Taman Siswa Jetis Yogayakarta", Junal Pendidikan Ke-Sdan. Vol.4, no.1

Damayanti, D., \& Nurgiyantoro, B. (2018). Local Wisdom as Learning Materials: Character Educational Values of Sundanese Pupuh. Journal of Education and Learning (EduLearn), 12(4), 676684.

Husain, B. (2016). Penggunaan Media AudioVisual Berbasis Kearifan Budaya Lokal Pada Pembelajaran Bahasa Inggris untuk Menanamkan Sikap Nasionalisme. Jurnal Pendidikan "Dodotp". Vol. 12. No.12

Kamus Besar Bahasa Indonesia. (2011). Departemen Pendidikan dan Kebudayaan Republik Indonesia.

Maksudin. (2013). Pendidikan Karakter NonDikatomik. Yogyakarta: Pustaka Belajar 
Muslich, M. (2011). Pendidikan Karakter: Menjawab Tantangan Multidimensional, Jakarta: Bumi Aksara

Mustika, I.K. (2018). “ Local Wisdom-Based Character Education in Teaching Balines to Achieve National Integration of a Nation". SHS Web of Conferences. 42. 00013

Samani, M \& Hariyanto. (2011). Konsep dan Model Pendidikan Karakter. Bandung: Remaja Rosdakarya

Sularso. (2016). Revitalisasi Kearifan Lokal dalam Pendidikan Dasar. Jurnal Pendidikan Sekolah dasar. Vol.2, No.1

Sulasmono, P. (2017). The Integration Of Local Cultural Wisdom Values in Building the Character Education on Studens, Internasional Journal of Education and Research, Vol. 5, No. 6.
Nursyifa, A. (2018). Kajian Cultural Lag dalam Kehidupan Masyarakat Perkampungan Budaya Betawi Setu Babakan Pada Era Globalisasi. Jurnal Pendidikan Kewarganegaraan, 5(1), 124.

Wamaungo, A.J. (2012). Mendidik untuk Membentuk Karakter. Jakarta: Bumi Aksara

Wibowo, A. (2012). Pendidikan Karakter: Strategi Membangun Karakter Bangsa Berperadaban.Yogyakarta: Pustaka Belajar.

Zubaedi. (2011). desain Pendidikan Karakter: Konsep dan aplikasinya dalam Lembaga Pendidikan. Jakarta: Kencana 